\title{
ORGANIZATION OF THE DEOXYRIBONUCLEIC ACID REPLICATING SYSTEM IN MAMMALIAN CELLS AS REVEALED BY THE USE OF X-RADIATION AND BROMURACIL DEOXYRIBOSIDE
}

\section{By Dr. ROBERT B. PAINTER and DR. RONALD E. RASMUSSEN}

Exobiology Division, National Aeronautics and Space

Administration, Ames Research Center, Moffett Field, California

IN previous work ${ }^{1}$, the action of $X$-radiation on synthesis of deoxyribonucleic acid (DNA) was shown to result in a dose-dependent depression of rate, as measured by incorporation of tritium-labelled thymidine. The doseresponse curve consisted of two components, one showing a very steep slope, the other a much shallower one. In those investigations incorporation of the tracer material was allowed to occur for 5-6 $h$, so that not only cells in the process of DNA synthesis ( $S$ period) at the time of irradiation incorporated the tracer, but also those cells in the pre-DNA synthesis $\left(G_{1}\right)$ phase during the irradiation that entered $S$ during the tracer incubation. In most of the work reported here, incubations for $1 \mathrm{~h}$ with tracers were used, so that predominantly $S$ cells were labelled, and the contribution from cells in $G_{1}$ can be ignored.

Among these experiments are ones in which the analogue of thymidine, bromuracil deoxyriboside (BUdR), was incorporated into the DNA of the cells before the irradiation. The results of this treatment have suggested an interpretation of the dose-dependent depression of DNA synthesis rate by $\mathrm{X}$-radiation and also permitted us to put forth a hypothesis concerning the sub-chromosomal organization of DNA.

Two kinds of cell culture were used in these investigations, HeLa $S 3$ and the Chinese hamster line, $D F A F-33$, kindly supplied by Dr. George Yerganian. The HeLa S3 culture was cultured routinely in Eagle's medium and transferred woekly; the $D F A F \mathbf{H 3}$ was cultured either in Eagle's or in the 'HU-15' medium of Elkind', and transferred twice a week. For experiments, $\mathrm{HeLa} S 3$ cells were transferred, in Eagle's medium, at about 2-4 $\times 10^{4}$ cells/ $\mathrm{ml}$, into any of 3 different kinds of culture vessels: $T$-30 flasks (5-ml./flask), Loighton tubes (1-ml./flask), or squaro centrifugible flasks (Bellco Glass, Vinoland, Now Jersey, 3-ml./flesk). $D F A F-33$ cells for experiments 
were always transferred into Eagle's medium, using the same array of culture vessels: incubations of HeLe S3 prior to the irradiations varied from 3 to 5 days; for $D F A F-33$ they were 2 or 3 days. In 3-day experiments, the media were changed on the second day; in 5-day experiments thoy were changed on the third day.

Irradiations were performed with two different units. The first, used in the earlier experiments, was a 4-m.amp, $250-k V p$. unit, with no external filtering; the dose rate was $100 \mathrm{r} \cdot / \mathrm{min}$. The other was a 20 -m.amp, 300-kVp. unit, also operated without external filtering; the dose rate, measured inside a tissue culture vessel, was from 200 to $300 \mathrm{r} . / \mathrm{min}$, depending on the number of cultures irradiated. All irradiations occurred on a rotating turntable, under conditions of minimal scatter, at room temperature.

Immediately after irradiation, the cultures, including the sham-irradiated controls, were returned to the laboratory, the media on them removed, and Eagle's medium containing the tracer added. The tracer used in most of the work was tritiated thymidine at $1 \mu \mathrm{c} . / \mathrm{ml}$., but the total thymidine of the medium was changed according to experimental requirements by the addition of unlabelled thymidine. Tritium-labelled uridine at $1 \mathrm{c} / \mathrm{mM}$ and ${ }^{14} \mathrm{C}$-guanine at $3 \mathrm{mc} . / \mathrm{mM}$ were also used at various times. All compounds were obtained from Now England Nuclear Corporation. After the $37^{\circ}$ incubation period (generally $1 \mathrm{~h}$ with exceptions as indicated later), the medium was rapidly removed from all cultures, and the cells processed to determine tho spocific ebtivity of DNA.

Three different methods for DNA extraction were used. One method, previously described by us ${ }^{1}$, was essentially that of Ogur and Rosen ${ }^{3}$ using perchloric acid to hydrolyse both RNA and DNA. The second was the Schmidt-Thannhauser method ${ }^{4}$, using overnight incubation with $1 \mathrm{~N}$ sodium hydroxide at $37^{\circ}$ to hydrolyse RNA and perchloric acid at $70^{\circ} \mathrm{C}$ for $1 \mathrm{~h}$ to release DNA. Tho third was an adaptation of tho method of Seotl et al." which uses $1 \mathrm{~N}$ sodium hydroxide for $1 \mathrm{~h}$ at room temperaturo to obtain RNA, hydrolysis with perchloric acid at $60^{\circ} \mathrm{C}$ for only $7 \mathrm{~min}$ to obtain the DNA fraction. All mothods gave qualitatively the same results, but the latter method guve the best reproducibility, that is, the lowest variability among similarly troated cultures. In all cases the DNA of each flask was estimater by reading the optical density of the DNA fraction at $267 \mathrm{mM}$, using a Beckman $D U$ spectrophotometer and semi-micro (volume about $1.5 \mathrm{ml}$.) cuvettes (Pyrocell Corp., Now York). Tho radioactivity of the fractions was detcrmined by dissolving 0.5 or $1.0 \mathrm{ml}$. of the samplo in $10 \mathrm{or} 15 \mathrm{ml}$. of counting solution $(13 \mathrm{~g}$ 2,5-diphenoloxazole, $0.25 \mathrm{~g}$ 1,4-bis-2-(5-phenyloxazolyl)benzene and $130 \mathrm{~g}$ naphthalene in a mixture of 11 . toluene, 1 1. dioxane and $600 \mathrm{ml}$. ethanol), and counting in a 


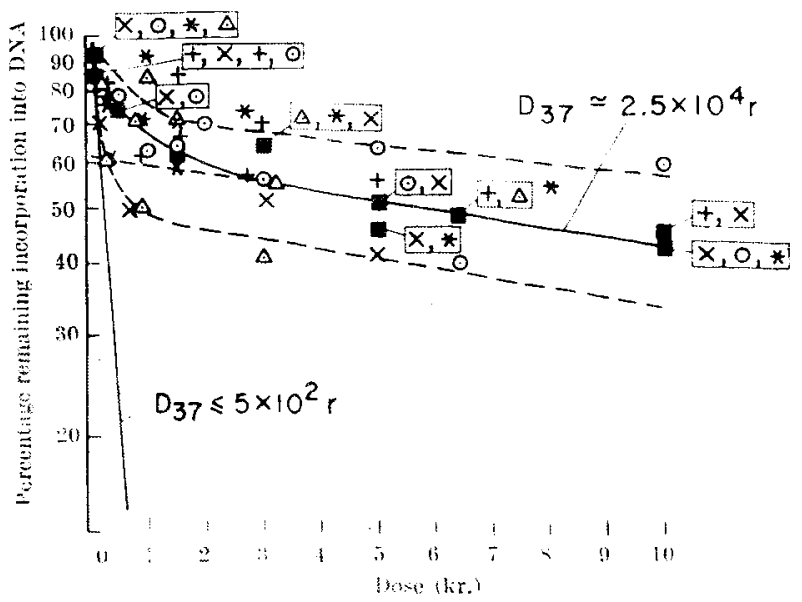

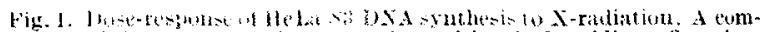
posite of fourtere preriments, ueing tritiated thymine of varims specific ictivities. Cach point is averate of ther two. three or four individual determinat ions. Dat ic plotted as unerentage of sham-irradiated

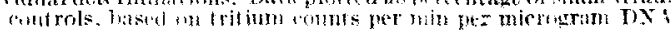

Packitrd Tri-Curb liquid seintillation spectrometer. When tritium and carbon-14 were in the same samples, the efficioncy of ach isotope for "ath channel was determined using ${ }^{3} \mathrm{H}$ - and ${ }^{14} \mathrm{C}$-tohene standards and the separate contributions of each isotope to tho funal counts ralculated by means of simultaneous equations ${ }^{2}$.

In experiments with bromuraril deoxyciboside (BLdR). uxperimental cultures were set up as usual; three days later the medium of one-half of the culture tubes was removed and replaced with Eaglin's medium eontaining $5 \mu \mathrm{g} / \mathrm{ml}$. BUdR $\left(1.6 \times 10^{-5} \mathrm{M}\right)$, and the medium of the other half of the tules was replaced with Eiagle's containing an equimolar :unount of thymidine (4 k $\mathrm{kr} / \mathrm{ml}$.). After two adelitional days incubation. these media were remoned. the colls washed oner with Hanks is balaneed salt solution and this solution was added to the flasks and gassed with is per eent earbon dioxide and 95 per cent air mixture. The Hasks were then irradiated. returned immediately to the laborutory, the Hanks's balianced salt solution remoral from them ind replaced with Eagle's medium containing the radioisotope(s),

The results of 14 experiments using $1 \mathrm{we} / \mathrm{m}$. tritiated thymidine as the trucer for INA synthesis in HeLa S3 cells are plotted in Fir. I. The concentration of thymidine variad from $1.5 \times 10^{-5}$ to $4 \times 10^{-2} \mathrm{M}$, that is the specific activity of the tritiated thrmidine in these experiments vatiod from 24 me. $\mathrm{mM}$ to $6.700 \mathrm{mo} / \mathrm{mM}$. There is no consistent effect of specifir activity. The variability that is evident form the sonter is much more the result 


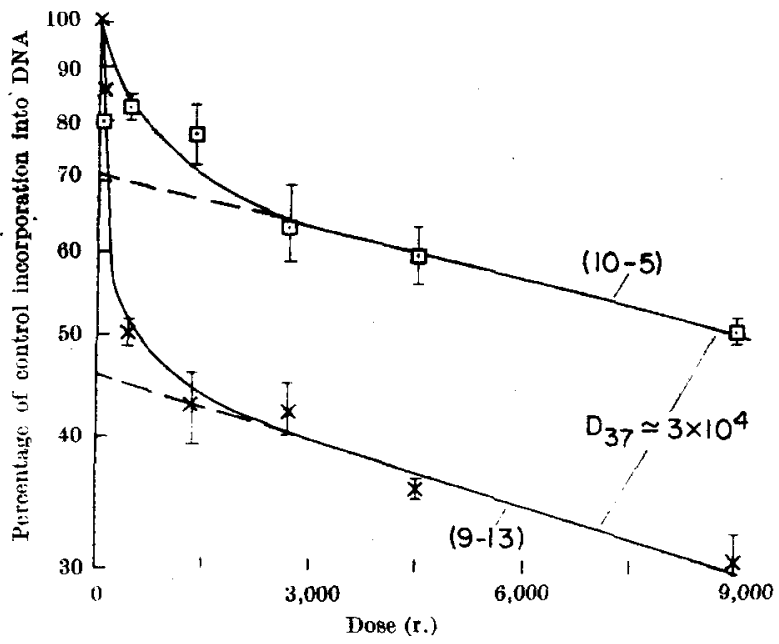

Fig. 2. Dose-response of $D F A F-33$ DNA synthesis to X-radiation. illustrating variation in participation of steep component

of dose-response differences between experiments thul from heterogeneity within an experiment. The maximum and minimum total inhibitions are plotted by extrapolation to zero dose; it appears that the fraction of the total inhibition due to the steep component varies between roughly 25 and 55 per cent. Two experiments with $D F A F-33$, shown in Fig. 2. demonstrate a similar variability. which is comparable to that reported by Lajtha et al. for bone marrow in culture ${ }^{6}$. Results with low specific activity ${ }^{14} \mathrm{C}$-gurnine at $10 \mu \mathrm{g} / \mathrm{ml}$., used in doublelabelling exporimonts with tritiated thymidine, are practically jdentical with those obtained with tritiated thymidine. and assure that the steep component is not due to a release of pool materials that compete with tracer for sites in IDNA.

The $D_{0}$ of the shallow componont of the curve varies as much as two-fold if values of individual experiments are plotted. However, the range of values from about 1.8 to $4 \times 10^{4} \mathrm{r}$. affects the estimated size of the hypotheticel target only by approxinuately two. On the othor hand. although it is rather difficult to measuro exactly the average $D_{n}$ of the steep component, it is so small, certainly less than $500 \mathrm{r}$, that the resulting target volumo must be very large.

The apparent extent of depression of DNA synthesis by $\mathrm{X}$-radiation increases as a function of time of incubation with tracer. This is illustrated in Table 1 and is similar to the results reported previously ${ }^{1}$. This observation indicates that cells that are in the $G_{1}$ compartment during 
Tahle 1 . Fintect of Post-IRRA DLATION INOUBaTION THE ON THE RADIATONDEPRESSED INCORPORATION OF $\mathrm{H}^{3} \mathrm{~T}$ TR INTO DNA

\begin{tabular}{|c|c|c|c|c|c|}
\hline \multirow[b]{2}{*}{$\begin{array}{c}\text { Exp. } \\
\text { No. }\end{array}$} & \multirow[b]{2}{*}{$\begin{array}{c}\text { Dose } \\
\text { (r.) }\end{array}$} & \multirow[b]{2}{*}{ incubation } & \multicolumn{3}{|c|}{ Specifle activity c.p.m./ $\mu \mathrm{g}$ DNA } \\
\hline & & & $\begin{array}{l}\text { Depression } \\
\text { (per cent) }\end{array}$ & $\begin{array}{l}3 \text { or } 4 h^{*} \\
\text { incubation }\end{array}$ & $\begin{array}{l}\text { Depression } \\
\text { (per cent) }\end{array}$ \\
\hline 1 & $\begin{array}{r}0 \\
100 \\
800\end{array}$ & $\begin{array}{l}377 \\
342 \\
295\end{array}$ & $\overline{9}$ & $\begin{array}{r}1,090 \\
808 \\
602\end{array}$ & $\begin{array}{l}\overrightarrow{26} \\
45\end{array}$ \\
\hline 2 & $\begin{array}{r}0 \\
500 \\
5,000\end{array}$ & $\begin{array}{l}339 \\
274 \\
177\end{array}$ & $\begin{array}{l}\overline{17} \\
47\end{array}$ & $\begin{array}{r}1,062 \\
634 \\
346\end{array}$ & $\begin{array}{l}\overline{42} \\
68\end{array}$ \\
\hline
\end{tabular}

- Incubation time following irradiation in $\operatorname{Exp} .1$ was $4 \mathrm{~h}$; in Exp. 2 it was $3 \mathrm{~h}$.

Table 2. FFFECT OF Low DOSES OF X-RADIATION ON UPTAKE OF TRTMTED THYMIDINE INTO DNA OF THYMIDINE-GROWE CELLS AND BROMURACT, DeOXYRIBOSIDE-grown CeIs

\begin{tabular}{|c|c|c|c|c|}
\hline $\begin{array}{c}\text { Dose } \\
(\mathbf{r} .)\end{array}$ & $\begin{array}{l}\text { Sp. act. of } \\
\text { thymidine- } \\
\text { grown cells }\end{array}$ & $\begin{array}{l}\text { Change } \\
\text { (per cent) }\end{array}$ & $\begin{array}{c}\text { Sp. act. of } \\
\text { BUdR- } \\
\text { grown cells }\end{array}$ & $\begin{array}{l}\text { Change } \\
\text { (per cent) }\end{array}$ \\
\hline 0 (control) & $\begin{array}{l}1,112 \pm 44 \\
1,008 \pm 50\end{array}$ & $-9 \overline{1}$ & $\begin{array}{l}678 \pm 27 \\
685 \pm 18\end{array}$ & +15 \\
\hline 162 & $980 \pm 60$ & $-12 i$ & $716 \pm 42$ & $+5 i^{+}$ \\
\hline
\end{tabular}

- Pooled means change in thymidlne-grown cells differs significantly

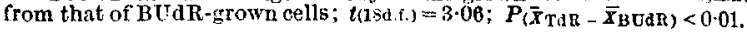

irradiation and enter the $S$ period during the next 3-4 h are affected roughly the same, in terms of rate of DNA synthesis, as cells in $S$ at the time of irradiation.

A typical result of the effect of BUdR incorporated into DNA on the dose-response of DNA synthesis is shown in Fig. 3; the dose-response curvo shows an increased incorporation of isotope into DNA over control values at low doses, followed by a dose-response practically identical to that observed with thymidine-grown cells. In order to establish further the reality of this difference, an experiment was performed using 5 replicato flasks per treatment, with controls and only two low doses, 52 and $162 \mathrm{r}$. The results (Table 2) show that these small doses slightly but. significantly depressed the incorporation into DNA of thymidine-grown cells, but had no effect on the BUdRgrown cells:. It is important to note that the effect of BUdR in sham-control cultures is to very markedly decrease the rate of DNA synthesis. The onhanced incorporation of tritiated thymidine into DNA by low doses of X-radiation occurred in about one-half the experiments and, in every instance except one (among 10 experiments), the effect of BUdR was to decresse the extent of depression of incorporation by small doses. We have never observed enhanced incorporation under any other circumstances. At higher doses the results paralleled those of normally grown or thymidine-grown cells so that there is no apparent effect on the second component of the dose response. It is possible that a subtle effect exists in this area, but, if so, it is hidden in the variability of the response.

The two-component dose-response curve is similar to 
those reported by Lejtha and co-workers for bone marrow in culture ${ }^{6}$, for bone marrow and ascites tumour cells by Jasinska and Michalowski ${ }^{7}$, and for rat thymus by Ord and Stocken ${ }^{6}$. A number of theories have been proposed to explain these results. In thymus, Ord and Stocken attiribute the steep fall (corresponding to the steep or $S_{1}$ component of the two-pert curve) to inhibition of nuclear phosphorylation, but this explanation, even if it were a general one (which it appears not to be), still does not explain the site of the damage. Although damage to an enzyme has been suggested ${ }^{6}$, this seems highly unlikely in terms of target theory, which would indicate that the molecular weight of the hypothetical onzyme would be in the order of $10^{9}$, clearly much greater than molecular weights of known enzymos.

Our results with BUdR lead us to an alternative explana. tion. This compotitor of thymidine for DNA thymine sites depresses the rate of synthesis of DNA, and since it is no longer available for incorporation from the medium at the time of this inhibition, it is the BUdR in the DNA. and presumably in those areas acting as templates for new synthesis, that contributes to this rate depression. A small dose of X-radiation, in many instances, partially roverses this inhibition. We propose that the incorporated BUdR distorts the organization of a large organized component of the DNA replicating systom that is necessary to maintain the maximal rate of replication of DNA. The size of this is estimated to be in the ordor of $1.0^{9}-10^{10}$. sinee a small dose $(500 \mathrm{r}$.) of $\mathrm{X}$-rays can affect it. The offect of a single hit on the BUdR-substituted DNA is sometimos to mako a now site available for synthesis so that a stimulation of rate may be observed. On the whole, however, the effect is to further the disorganization of this 'super molecule', and so larger doses result in depression of pate.

The concept of very-high-molecular-weight DNA is not new. The work of Davison", showing the effects of shear on molocular weight determinations, has stimulated a groat doal of recent work in this aresib. In generibl, the concept has evolved that the molecular woight of native DNA is very much largor than the often-quoted $1-8 \times 10^{B}$ found in the older literature. The researches of Cairns ${ }^{10}$ and of Kleinschmidt et al. ${ }^{11}$ have lod to the concept that : $l l$ the DNA in a bacterium like Escherichia coli (at loast, all the DNA in one nucleus therein) is in the form of ab single large molecule. Interestingly, the molocular weight of this DNA is about $10^{\circ}$.

According to Lee and Puck $^{12}$, the average content of DNA of the HeLa cell is $17 \mathrm{pg}$, or a total molecular weight of DNA per cell of about $10^{13}$. This is distributed, probably unequally, among 78 (on the average) chromosomes. Taking one of the smaller chromosomes to contain 


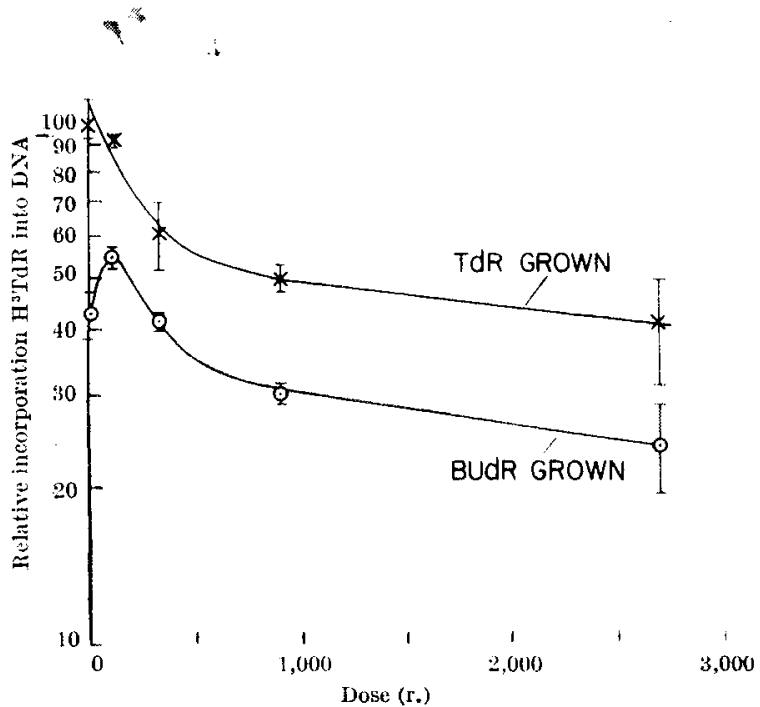

Fig. 3. Effect of bromuracil (leoxyriboside (13UdR) on dose-response of HeLa $\$ 3$ DNA synthesis to $\mathrm{X}$-radiation. $\mathrm{BUdR}$ cultures grown in presence of $5 \mu \mathrm{g} / \mathrm{ml}$. BUdR, controls in presence of $4 \mu \mathrm{g} / \mathrm{ml}$. thymidine (T'dR), for $48 \mathrm{~h}$ prinr to irradiation. All data plotted relative to specific activity of $\mathrm{TdR}$-grown control ( $\mathrm{H}^{3} \mathrm{Td} \mathrm{R}=$ tritiated thymidine)

roughly $1 / 100$ of the total DNA of the cell, its total DNA would bo about $10^{11}$. The target estimate of the large moloculo of DNA involved in regulating rate of DNA synthesis is $10^{9}-10^{10}$, so the chromosome would contain 10-100 of these components. That chromosomes do contain several 'roplicating units' is borne out by autoradiographic investigations that have shown DNA synthesis occurring simultaneously at two or more sites in a chromosome, while other parts of it show no evidence of replication ${ }^{13-15}$.

Even if the integrity of this large unit is completely destroyed (as by inactivation with $\mathrm{X}$-rays) DNA synthesis continues, but at a considerably diminished rate (shallow component), and only very large doses of radiation, capable of inactivating that DNA acting as a 'tomplate', can significantly depress the rate furthor. These results indicate that DNA of molecular weight of about $10^{7}$ is 'activated' for replication at any one time.

Our interprotation is strengthened by tho results of Lehnert and Okada ${ }^{16}$, who havo shown that an effect of X-radiation on DNA synthesis rate in nucloi of regenorating rat liver can be observed so long as protein is still in association with DNA, but no effect is found with purified DNA alone. Walwick and Main ${ }^{17}$ have also reported no effect of ionizing radiation, up to $10,000 \mathrm{r}$., on the rate of DNA synthesis in a enll-freo system using purified DNA ats primer. These kincls of investigations point out the 
limitations of in vitro biochemical methods, wherein maximum mixing of components and completely unorganized systems are used, as a means for determining effects on the highly ordered state of subcellular organization. It is probable that when purified 'primer' DNA is used in in vitro reactions it is at a nuch lower molerular weight than in the cell. Moreover, it is removed from restrictions on its reaction probability by being free of protein, now greatly implicated in the function of DNA as a template for RNA (particularly 'messenger' RNA) synthesis ${ }^{18-20}$. It is not surprising that ionizing radiation cannot reduce the efficiency of DNA as a primer under these conditions where there is at all times a maximum likelihood of its interaction with the enzyme and precursors. Inde日d, if the action of ionizing radiation is primarily to reduce the size of the primer unit, it could conceivably take enough radiation to reduce the average molecular weight to somewhere less than 10,000, which is the molecular weight of yeast lactic dehydrogenaseassociated $\mathrm{DNA}^{21,22}$, shown to act as a primer for in vitro DNA roplication ${ }^{23}$.

1 Palnter, R. B., Rad. Res., 16, 846 (1962).

- Elkind, M. M., and Sutton, H., Rad. Res., 13, 556 (1960):

s Ogur, M., and Rosen, G., Arch. Biochem., 25, 262 (1950).

- Schmidt, G., and Thannhauser, S. J., J. Biol. Chem., 161, 83 (1945).

- Seott, J. F., Fraccastoro, A. P., and Taft, E. P., J. Histochem. Cytochem. 4, 1 (1956).

- Lajtha, L. G., Oliver, R., Berry, R., and Noyes, W. D., Nature, 182, 1788 (1958).

${ }^{7}$ Jasinska, J., and Michalowskj, A., Nature, 196, 1326 (1962).

Ord, M. G., and Stocken, L. A., Nature, 182, 1787 (1958).

- Davison, P. F., Nature, 185, 918 (1960).

${ }^{10}$ Cairns, J., J. Mol. Biol., 4, 407 (1962).

$"$ Kleinschmidt, A., Lang, D., and Kahn, R. K., Z. Naturf., 16, b, 730 (1961).

19 Loe, H. H., and Puck, T. T., Rad. Res., 12, 340 (1960).

is Palnter, R. B., J. Biophys. Biochem. Cytol., 11, 485 (1961).

is Stubblefield, E., and Mueller, G. C., Cancer Res., 22, 1091 (1962).

15 Taylor, J. H., J. Biophys. Biochem. Cytol., 7, 455 (1960).

16 Lehnert, S. M., and Okada, S., Nature, 199, 1108 (1963).

"Walwick, E. R., and Main, R. K., Biochim. Biophys. Acta, 55, 225 (1962).

18 Huang, R. C., and Bonner, J., Proc. U.S. Nat, Acad. Sci., 48, 1216 (1962).

${ }^{10}$ Allfrey, V. G, Littau, V. C., and Mirsky, A. E., Proc. U.S. Nat. Acad. Sci., 49, 414 (1963).

s0 Hindley, J., Biochem. Biophys. Res. Comm., 12, 175 (1963).

"Appleby, C. A., and Morton, R. K., Biochem. J., 71, 492 (1959).

"Mahler, H. R, and Pereira, A. J. S.. J. Mol. Biol., 5, 325 (1962).

${ }^{23}$ Bollum, F. J., in Progress in Nucleic Acid Research, edit. by Davidson, J. N., and Cohn, W. E, 1, 1 (Academic Press, New York, 1963). 